\title{
The case of atmospheric pollution using production waste in a building materials factory: an applied industrial case
}

\author{
F. Patania, A. Gagliano, F. Nocera, A. Galesi \& A. D’Amico \\ Energy and Environment Division of DIIM, \\ Engineering Faculty of University of Catani, Italy
}

\begin{abstract}
The disposal of dangerous or special waste by combustion represents significant global atmospheric pollution even though emission limits do tend to curb greenhouse gases.

The hazardous industrial waste must be treated, stored or disposed of utilizing a large amount of energy and petroleum. So the use of such waste as a 'raw material' in the production of building materials not only reduces the waste to dispose of, but also the emission of atmospheric pollutants.

On this basis, research into the facilities of the DB Group (a large brick producer) has brought about a change in the raw materials used in production by using about $20 \%$ waste products without any significant variation in the end product.

Considering the above, this study wants to show: 1 . the plant modifications to allow mixed raw material input; 2 . the environmental control techniques used; 3. the beneficial results for atmospheric pollution.

Keywords: pollution, reuse, waste production.
\end{abstract}

\section{Generality}

The DB Group is a brick producer and utilizes low volumes of fly ash generated from the Enel Power Station as a raw material to substitute for a part of the clay and shale, which are the two main raw materials of a conventional brick

The development and marketing of commercial bricks that contain dry and pond fly ash and other waste should benefit the Enel Power Station and the brick 
manufacturer by reducing the disposal of waste by-products and providing an economical brick ingredient

Although the incorporation of waste in fired brick has previously been studied worldwide using various formulations and different fly ash, there are no reported studies on using Enel Power Station fly ash.

So the authorities wanted to know the environmental impacts of the technology that was adopted by the DB Group brick industry. They were especially interested to know how the raw material influenced the atmospheric emissions of the brick manufacture stacks.

We know that models are useful tools to utilize when estimating environmental impacts from development projects and setting up proper mitigation policies of the Environment Impact Assessment.

Especially with regard to air quality, models are indispensable tools for evaluation. Thus, the selection and application of proper models is one of the most important factors for making reliable and accurate assessments.

The purpose of this study is to quantitatively evaluate the impacts and the atmospheric emissions of a brick manufacture both with the application of the US-EPA Industrial Source Complex Model (ISC) and measurements campaign.

\section{The investigated area}

The DB Group is located in the industrial area of Adrano, which is a little town in Sicily. It is situated around $41 \mathrm{~km}$ northwest of Catania, which is also the capital of the province to which Adrano belongs. It lies near the foot of Mount Etna, at the confluence of the Simeto and Salso Rivers.

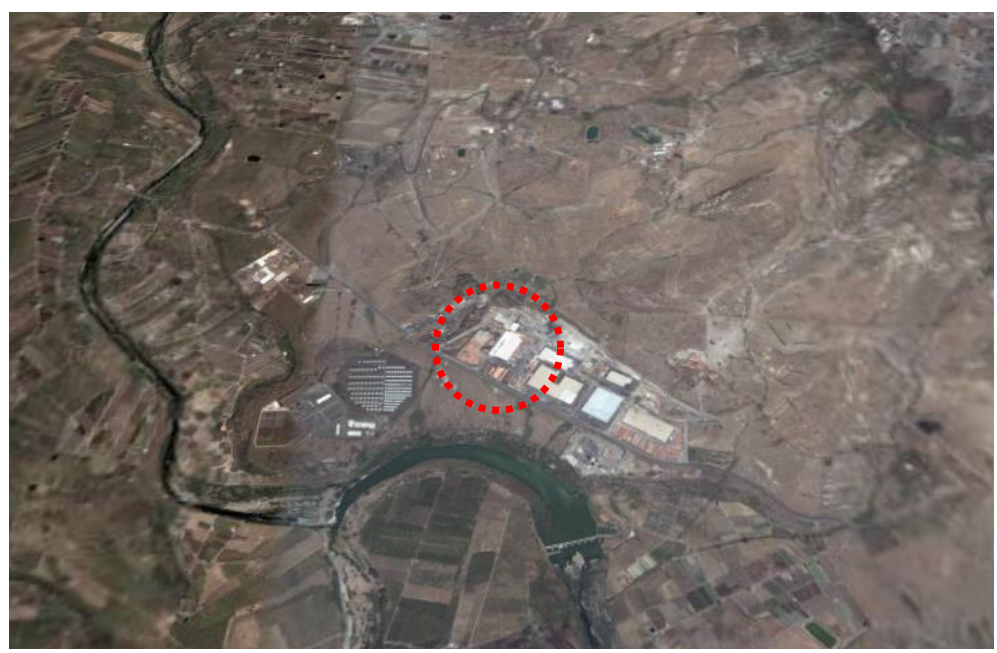

Figure 1: Investigated area. 


\section{Process description}

Although the basic principles of manufacture are fairly uniform, individual manufacturing plants tailor their production to fit their particular raw materials and operation. Essentially, bricks are produced by mixing ground clay with water, forming the clay into the desired shape, and then drying and firing the bricks. In our case the manufacturing process has six general phases: mining and storage of raw materials, preparing raw materials, forming the brick, drying, firing and cooling and de-hacking and storing finished products.

Surface clays, shales and some fire clays are mined in open pits with power equipment. Then the clay or shale mixtures, with other non-dangerous waste coming from other industries, are transported to an open plant storage area bordered by trees. Furthering that, raw materials are wet by several sprinklers to avoid the dispersions of particulate matters in the atmosphere. The hazardous fly ash is transported from the Power Station to a closed plant area where the bad smells are controlled by suitable filters.

Bricks are made of $65 \%$ clay, $25 \%$ non-dangerous waste and $10 \%$ hazardous fly ash. Before the firing process begins, most of the water, contained in the bricks, is evaporated in dryer chambers at temperatures ranging from $38^{\circ} \mathrm{C}$ to $204^{\circ} \mathrm{C}$. The dryer chambers are heated with waste heat from the kiln cooling zone and have supplemental gas burners that produce small amounts of NOx, $\mathrm{CO}$, and $\mathrm{CO}_{2}$ emissions. It is important to evaluate emission concentration coming from n.13 stacks of dryer chambers because they could exceed the Air Quality Standards. Bricks are then fired in a tunnel kiln heated by a 2 MW CHP plant.

\section{Emissions}

Emissions from brick manufacturing facilities include particulate matter (PM), PM less than or equal to 10 microns in aerodynamic diameter (PM-10), PM less than or equal to 2.5 microns in aerodynamic diameter (PM-2.5) sulfur dioxide $\left(\mathrm{SO}_{2}\right)$, sulfur trioxide $\left(\mathrm{SO}_{3}\right)$, nitrogen oxides $(\mathrm{NOx})$, carbon monoxide $(\mathrm{CO})$, carbon dioxide $\left(\mathrm{CO}_{2}\right)$, metals, total organic compounds (TOC) (including methane, ethane, volatile organic compounds (VOC), and some hazardous air pollutants (HAP)), hydrochloric acid ( $\mathrm{HCl})$, and fluoride compounds.

Factors that may affect emissions include raw material composition and moisture content, kiln fuel type, kiln operating parameters, and plant design. The primary sources of PM, PM-10, and PM-2.5 emissions are the raw material grinding and screening operations and the kilns. Combustion products, including $\mathrm{SO}_{2}, \mathrm{NOx}, \mathrm{CO}$, and $\mathrm{CO}_{2}$, are emitted from fuel combustion in brick kilns and some brick dryers. Organic compounds, including methane, ethane, VOC, and some HAP, are emitted from both brick dryers and kilns. Hydrogen fluoride (HF) and other fluoride compounds are emitted from kilns as a result of the release of the fluorine compounds contained in the raw material.

Fluorine typically is present in raw brick materials in the range of 0.01 to 0.06 percent. As the green bricks reach temperatures of $500^{\circ} \mathrm{C}$ to $600^{\circ} \mathrm{C}$, the 
fluorine in the raw material forms HF and other fluorine compounds. Much of the fluorine is released as HF. Because fluorine content in clays and shales is highly variable, emissions of $\mathrm{HF}$ and other fluoride compounds vary considerably depending on the raw material used.

\section{ISC3-model}

The US-EPA Industrial Source Complex Model (ISC), originally developed over 20 years ago by the US-EPA, is now in its third version (ISC3). There are two versions of ISC3, a short-term model (ISCST3) and a long-term model (ISCLT3). The models differ in the averaging times available for calculation, available terrain and deposition options, and the format of input meteorological data. The ISC3 algorithm is regularly updated by the US-EPA and can be obtained free via the Internet from the US-EPA's website. The basic "free to all" ISC3 model is not as easy to use in terms of the user interface and digitisation of input data, but several software companies have produced proprietary programmes that incorporate the ISC3 model with a user-friendly GUI that simplifies the data entry and checking procedures. An example is the Breeze Air ISC3 model, by Trinity Consultants Inc. (USA), which is utilized to evaluate the atmospheric emissions of the brick manufacture.

An interesting feature of ISC3 is the characterisation of a new source type "Open Pit Sources", for modelling dry deposition of particulates from open pit sources. ISC3 also includes both states of the science dry and wet deposition algorithms. This kind of feature of ISC3 is useful to evaluate the emissions of the plant storage area of the brick manufacture. Dispersion models require a number of user specified input parameters. Some of these may vary with each type of model scenario; others rarely require alterations and shouldn't be changed from the model default. The most significant and commonly used model parameters include the following:

- Dispersion coefficients (i.e. land use classification, rural or urban)

- Plume rise

- Building wake effects

- Terrain effects

- Surface roughness

- Wind direction and wind speed

- Receptor grids.

The type of dispersion coefficient used can have a significant impact on dispersion model predictions. The standard procedure for determining whether rural or urban classification is more appropriate to classify the land use within a $3 \mathrm{~km}$ radius circle about the source. If more than $50 \%$ of this area is urban then urban dispersion coefficients should be used, otherwise rural coefficients should be used. In our case then rural coefficients was used. The effects of plume rise, which can be simulated by ISC3 include:

- No buoyancy induced dispersion

- Gradual plume rise 
- Partial penetration of inversion layers

- No stack tip downwash.

We have taken into account both gradual plume rise and partial penetration of inversion layers. ISC3 have inbuilt algorithms to simulate the effects of building wakes and we have utilized a programme called BPIP (available on the Internet at the US-EPA's website) to determine the necessary parameters for downwash algorithms. This programme works out what obstacle dimensions are appropriate as a function of wind direction. Output from BPIP was incorporated into both ISC3

\section{The simulation data}

As shown in figure 2 the chosen domain of calculus, in Cartesian coordinates, has the following dimensions:

\begin{tabular}{|l|l|l|}
\hline $\mathrm{X}$ direction & Y direction & Z direction \\
\hline $3.300 \mathrm{~m}$ & $3.300 \mathrm{~m}$ & $150 \mathrm{~m}$ \\
\hline
\end{tabular}

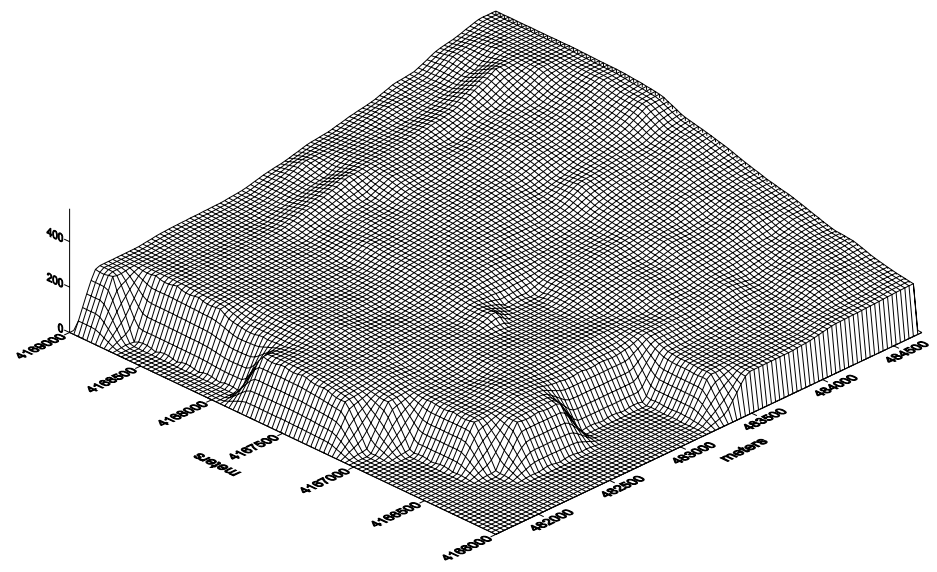

Figure 2: 3D-domain.

The domain is characterized by a grid with dimensions of $150 \mathrm{~m} \times 150 \mathrm{~m}$, n. 158 buildings, $n .16$ point sources emissions and $n .1$ area source emission.

People modelled terrain and buildings both by the available cartography at scale 1:2000 and by inspections carried out in the area. Authors adopted particulate matter (PM) and sulfur dioxide $\left(\mathrm{SO}_{2}\right)$ as tracer gases, to valuate the atmospheric emissions and the air quality impacts. ISC3 requires hourly meteorological data to estimate plume dispersion. According to EPA's Guideline on Air Quality Models, five years of adequately representative data should be used (when available) to account for year-to year variation. The model simulation has been done with the data coming from the Agrometereological Station of Sicily Environmental Department that is located 5 kilometers $(\mathrm{km})$ 
west of Adrano. The meteo input is based on hourly data of flow vector, wind speed, ambient temperature, stability class, rural mixing height and urban mixing height recorded by the Meteoclimatic Station from $1^{\text {st }}$ January 2006 to $15^{\text {th }}$ November 2006

The authors take into account three possible scenarios: the bricks are made without fly ash; with $10 \%$ hazardous fly ash; and with the maximum rate of hazardous fly ash allowed by air quality regulation. The emission sources characteristics are shown in tables 1, 2 and 3.

Table 1: $\quad$ Emission sources scenario without fly ash.

\begin{tabular}{|l|l|l|l|l|l|}
\hline & $\begin{array}{l}\text { Air } \\
\text { Flow } \\
\mathrm{Nm}^{3} / \mathrm{h}\end{array}$ & $\begin{array}{l}\mathrm{SO}_{2} \\
\mathrm{mg} / \mathrm{Nm}^{3}\end{array}$ & $\begin{array}{l}\mathrm{PM} \\
\mathrm{C} \\
\mathrm{mg} / \mathrm{Nm}^{3}\end{array}$ & $\begin{array}{l}\text { Temp } \\
\mathrm{K}\end{array}$ & $\begin{array}{l}\text { Velocity } \\
\mathrm{m} / \mathrm{s}\end{array}$ \\
\hline $\begin{array}{l}\text { Stack n.1 - 13 (dryer } \\
\text { chambers) }\end{array}$ & 15679 & 100 & 7 & 313 & 17.4 \\
\hline Stack n.14 (kiln) & 34650 & 100 & 5 & 378 & 9.5 \\
\hline $\begin{array}{l}\text { Stack n.15-16 (preparing } \\
\text { raw materials) }\end{array}$ & - & - & - & 288 & 5 \\
\hline
\end{tabular}

Table 2: $\quad$ Emission sources scenario with 10\% hazardous fly ash.

\begin{tabular}{|l|l|l|l|l|l|}
\hline & $\begin{array}{l}\text { Air } \\
\text { Flow } \\
\mathrm{Nm}^{3} / \mathrm{h}\end{array}$ & $\begin{array}{l}\mathrm{SO}_{2} \\
\mathrm{mg} / \mathrm{Nm}^{3}\end{array}$ & $\begin{array}{l}\mathrm{PM} \\
\mathrm{mg} / \mathrm{Nm}^{3}\end{array}$ & $\begin{array}{l}\text { Temp } \\
\mathrm{K}\end{array}$ & $\begin{array}{l}\text { Velocity } \\
\mathrm{m} / \mathrm{s}\end{array}$ \\
\hline $\begin{array}{l}\text { Stack n.1 }-13 \text { (dryer } \\
\text { chambers) }\end{array}$ & 15679 & 100 & 7 & 313 & 17.4 \\
\hline Stack n.14 (kiln) & 34650 & 100 & 5 & 378 & 9.5 \\
\hline $\begin{array}{l}\text { Stack n.15-16 (preparing } \\
\text { raw materials) }\end{array}$ & $18000-$ & - & 5 & 288 & 5 \\
\hline
\end{tabular}

Table 3: Emission sources scenario with the maximum rate of hazardous fly ash.

\begin{tabular}{|l|l|l|l|l|l|}
\hline & $\begin{array}{l}\text { Air } \\
\text { Flow } \\
\mathrm{Nm}^{3} / \mathrm{h}\end{array}$ & $\begin{array}{l}\mathrm{SO}_{2} \\
\mathrm{mg} / \mathrm{Nm}^{3}\end{array}$ & $\begin{array}{l}\mathrm{PM} \\
\mathrm{mg} / \mathrm{Nm}^{3}\end{array}$ & $\begin{array}{l}\text { Temp } \\
\mathrm{K}\end{array}$ & $\begin{array}{l}\text { Velocity } \\
\mathrm{m} / \mathrm{s}\end{array}$ \\
\hline $\begin{array}{l}\text { Stack n.1 - 13 (dryer } \\
\text { chambers) }\end{array}$ & 15679 & 500 & 50 & 313 & 17.4 \\
\hline Stack n.14 (kiln) & 34650 & 500 & 50 & 378 & 9.5 \\
\hline $\begin{array}{l}\text { Stack n.15-16 } \\
\text { (preparing raw } \\
\text { materials) }\end{array}$ & $18000-$ & - & 50 & 288 & 5 \\
\hline
\end{tabular}

\section{Results}

Figures 3 through 8 are maps that show examples of results of calculations of the maximum hourly concentration of $\mathrm{PM}$ and $\mathrm{SO}_{2}$. 


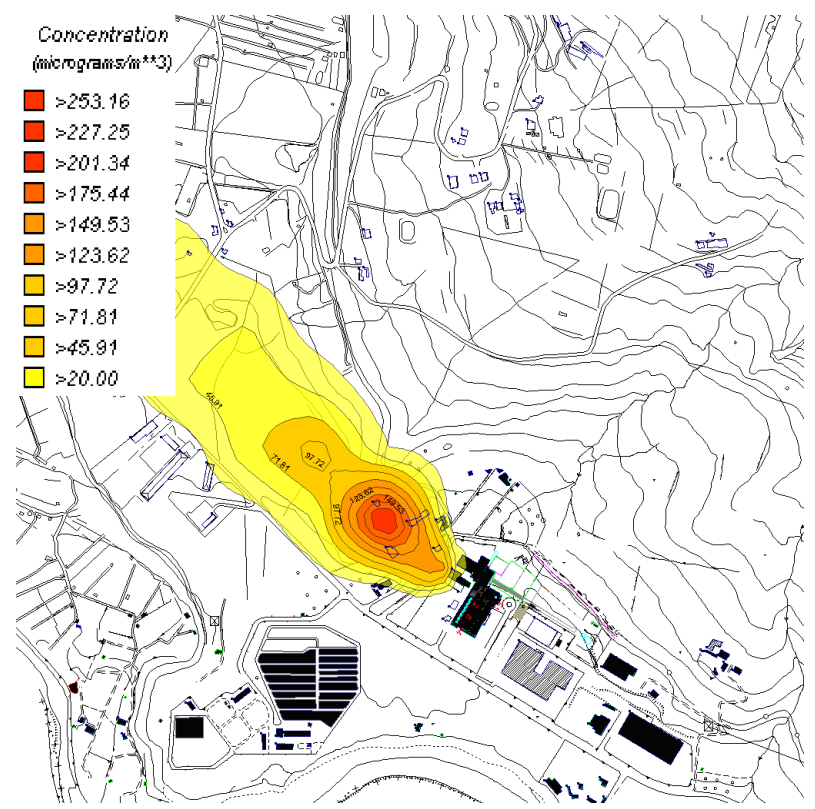

Figure 3: $\quad$ Scenario $1-$ iso-concentration $-\mathrm{SO}_{2}-\mathrm{V}=1.3 \mathrm{~m} / \mathrm{s}-\mathrm{Dir}: 135^{\circ}$.

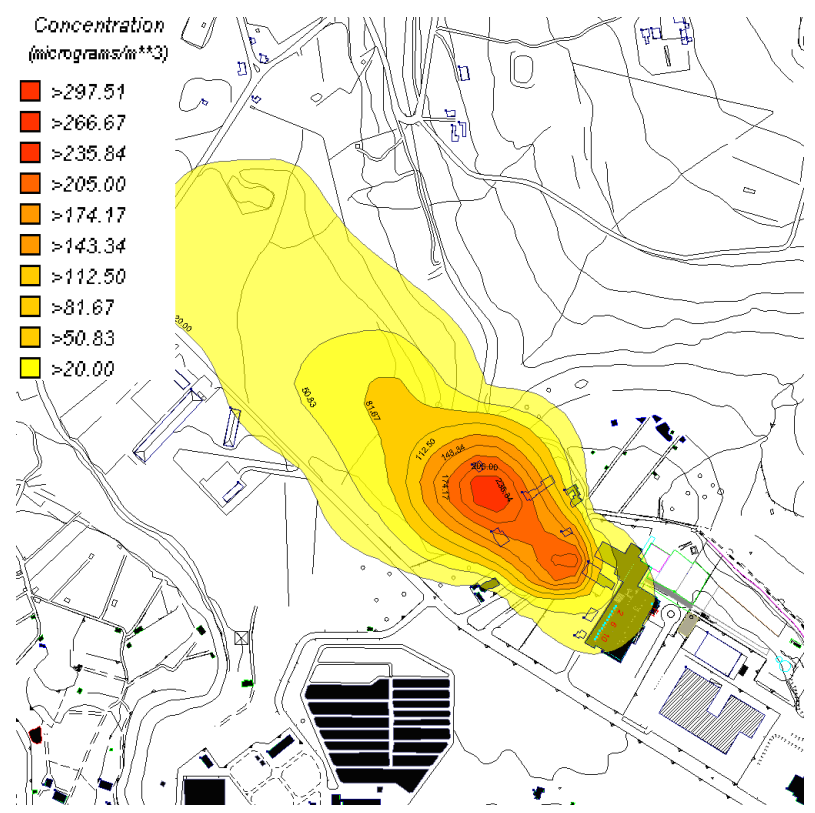

Figure 4: $\quad$ Scenario $2-$ iso-concentration $-\mathrm{SO}_{2}-\mathrm{V}=1.3 \mathrm{~m} / \mathrm{s}-\mathrm{Dir}: 135^{\circ}$. 


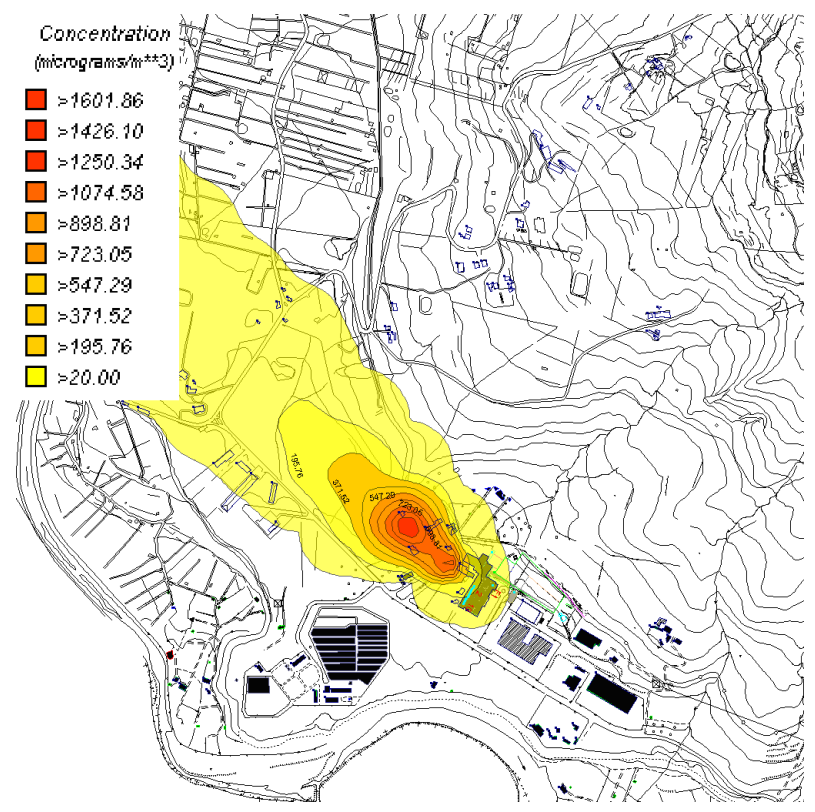

Figure 5: Scenario $3-$ iso-concentration $-\mathrm{SO}_{2}-\mathrm{V}=1.3 \mathrm{~m} / \mathrm{s}-$ Dir: $135^{\circ}$.

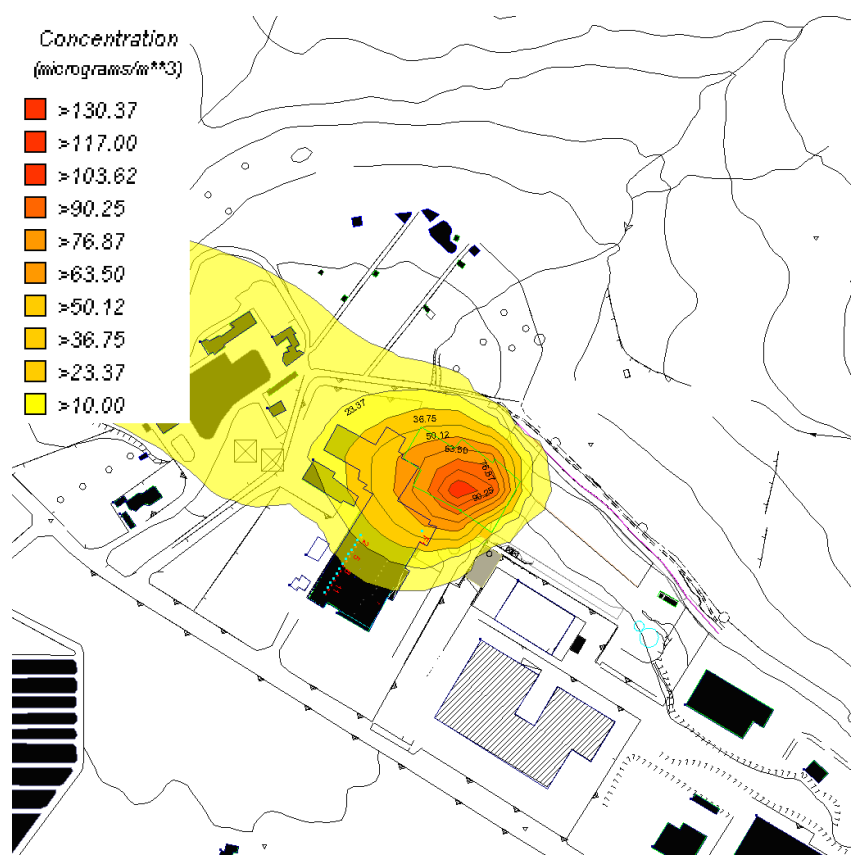

Figure 6: $\quad$ Scenario $1-$ iso-concentration $-\mathrm{PM}-\mathrm{V}=1.3 \mathrm{~m} / \mathrm{s}-\mathrm{Dir}: 135^{\circ}$. 


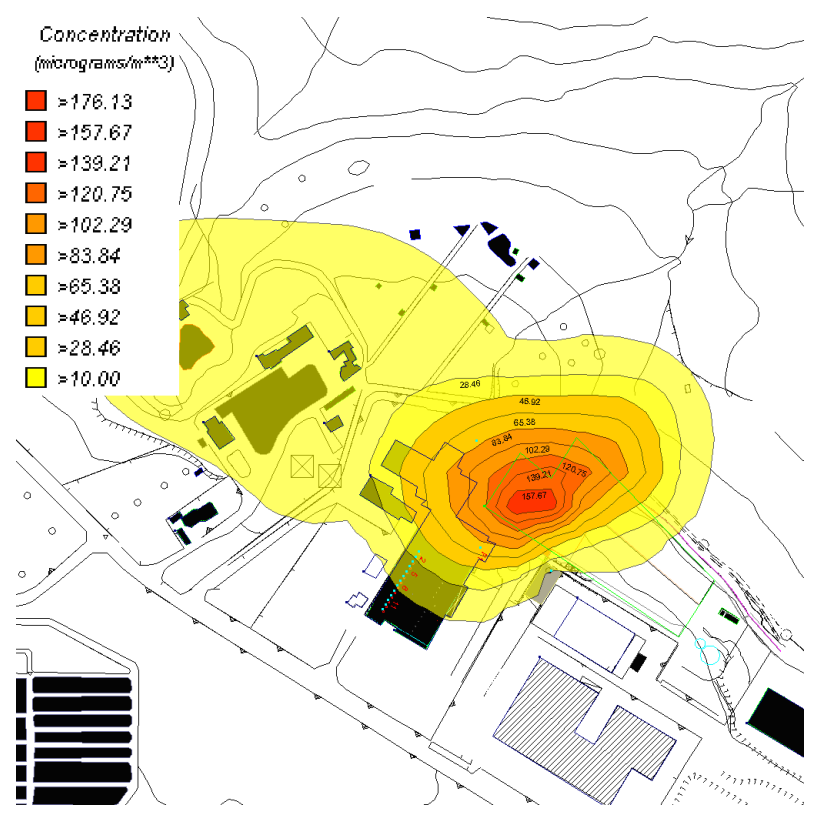

Figure 7: $\quad$ Scenario $2-$ iso-concentration $-\mathrm{PM}-\mathrm{V}=1.3 \mathrm{~m} / \mathrm{s}-\mathrm{Dir}: 135^{\circ}$.

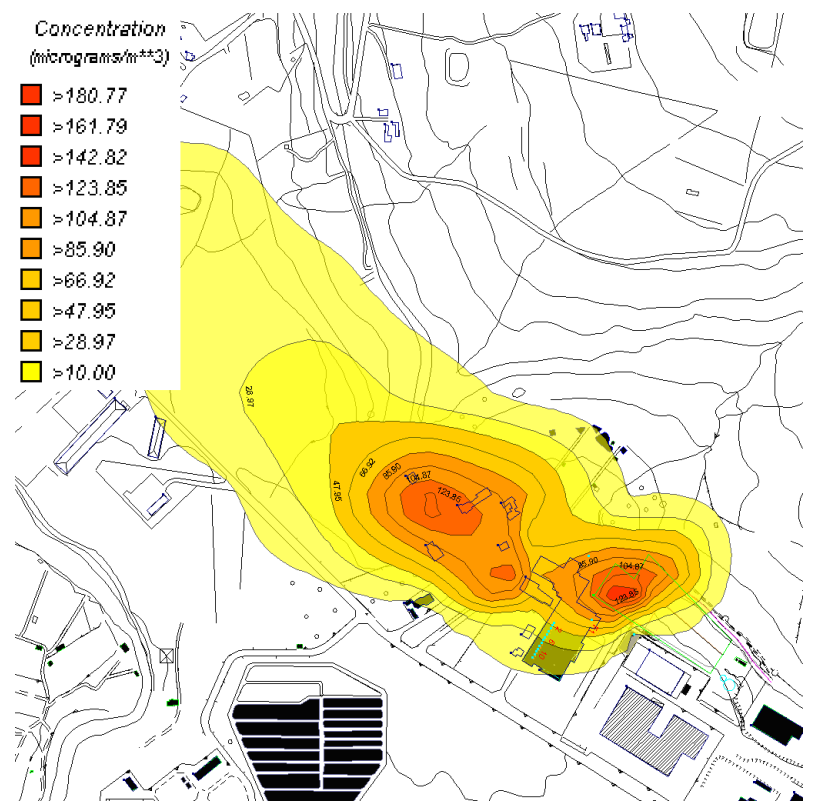

Figure 8: $\quad$ Scenario $3-$ iso- concentration $-\mathrm{PM}-\mathrm{V}=1.3 \mathrm{~m} / \mathrm{s}-\mathrm{Dir}: 135^{\circ}$. 


\section{Control systems}

So in the case of the maximum rate of hazards utilized by manufacture it needs to apply a variety of control systems, which may be used to reduce emissions from brick manufacturing operations. Grinding and screening operations must be controlled by fabric filtration systems. Particulate matter emissions from fugitive sources such as paved roads, unpaved roads, and storage piles can be controlled using wet suppression techniques (sprinklers). Dry scrubbers that use limestone as a sorption medium may be used to control HF emissions. Applying the previous control systems the values of polluting emissions, also utilizing maximum rates of hazardous fly ash, may be re-established to the acceptable values with the reference to an industrial area

\section{Conclusions}

From analysis of the plot of the concentration value it is possible to underline the following results:

- The reusing of low volumes of fly ash in the amount reported by the manufacture doesn't significantly increase the emission of $\mathrm{SO}_{2}$ in atmosphere.

- The PM emission in the atmosphere, due the raw material grinding and screening operations and the kilns, indeed it increases by about $25 \%$, however below the limit allowed by air quality regulation

- If the brick's manufacture process utilizes the maximum rate of hazardous fly ash allowed by air quality regulation, certainly the $\mathrm{SO}_{2}$ and $\mathrm{PM}$ concentrations will achieve values upper than those ones tolerable by human health. In that case it needs to apply a variety of control systems to reduce emissions from brick manufacturing operations, such as: grinding and screening operations must be controlled by fabric filtration systems; particulate matter emissions coming from fugitive sources such as paved pr unpaved rods, storage piles and so on must be carefully controlled by wet suppression techniques (sprinklers); control of HF Emissions must be done by dry scrubbers using limestone as sorption medium.

Applying the previous control systems the values of polluting emissions, caused by application of maximum rates of hazardous fly ash, may be reestablished to the acceptable values with the reference to an industrial area. Moreover, and in a more simple way, the use of "raw materials", in building materials production, could be done without dangerous effects to human health if the local authorities consent such kind of processes only underneath the conditions to fix the rate of hazardous materials that can be utilized in the function of both the real status of air pollution in the situ of factory and the more unfavorable meteoclimatic condition for gas dispersion.

\section{References}

[1] Industrial Source Complex (ISCST3) model, EPA modeling guidelines 
[2] F. Patania, A. Gagliano, F. Nocera, A. Galesi, A. Belluardo, The environmental control of air pollution by emission of gases coming from refineries through flow-dynamics modeling: an experimental feasibility test Air Pollution XIII, Editors C.A. Brebbia. L.C. WIT Press (UK). (2005) pp 22-33 